\title{
A blockmodel study of managerial hierarchies, verbal networks, and organizational culture in four hospitals
}

\author{
Reed Elliot Nelson \\ Uninove Graduate School of Management
}

\begin{abstract}
This study demonstrates and applies a social network methodology for studying the dynamics of hierarchies in organizations. Social network (blockmodel) analysis of verbal networks in four hospitals contrasted hierarchical and structurally equivalent partitions of the sociomatrices of frequent ties and perceptions of organizational culture. It was found that the verbal networks in these organizations follow a center periphery pattern rather than a hierarchical logic and that perceptions of culture vary more by verbal network than by formal hierarchy. The perceptions of culture of central groups in one organization are much like those of peripheral groups in another. In all four hospitals, structurally equivalent social networks are more important in predicting subcultures than are hierarchical groupings and hierarchy has a limited impact on the development of verbal networks. These findings suggest the value of an amoeba rather than a pyramid metaphor in interpreting the cultures and relational structures of organizations.
\end{abstract}

KEY WORDs: hierarchy; social networks; organizational culture; center-periphery.

Um estudo blockmodel de hierarquias gerenciais

Esta pesquisa ilustra uma metodologia de análise de redes sociais para o estudo das hierarquias nas organizações. A análise de blockmodels das redes verbais em quatro hospitais comparou partições estruturalmente equivalentes de redes verbais e critérios hierárquicos formais em relação às percepções de cultura organizacional. Constatou-se que as redes verbais dessas organizações formam uma configuração de centro-periferia em vez de uma configuração hierárquica. Constatou-se também que as percepções de cultura variam mais pela rede social verbal que pela hierarquia formal. As percepções de grupos centrais em um hospital são parecidas com as dos grupos periféricos de outro. Em todos os quatro hospitais as redes sociais estruturalmente equivalentes são mais importantes para a identificação das percepções culturais do que a hierarquia formal, e a hierarquia formal tem um papel limitado na formação de redes verbais. Estes resultados ressaltam a importância da metáfora da ameba, em vez da pirâmide, para interpretar as culturas e estruturas relacionais nas organizações.

Palavras-chave: hierarquia; redes sociais; cultura organizacional; centro-periferia.

Artigo received in Oct. 2010 and accepted in Aug. 2011.

RAP - Rio de Janeiro 46(1):291-314, jan./fev. 2012 
The classical organizational hierarchy assigns a number of subordinates to a superior who in turn is one of a number of subordinates reporting to a superior. This pattern repeats itself until one person or body with ultimate responsibility for the entire organization is reached (Weber, 1968). In the most extreme conceptualizations, contacts between subordinates are either prohibited or officially ignored such that coordination or dispute resolution is effected through the convergence of the appeals of separate subordinates to common superiors (Bennis, 1973; Lawrence and Lorsch, 1967; Nickerson and Zenger, 2004).

Both the accuracy of hierarchy as a description of real organizations and its merit as a prescriptive model have been debated over the years - usually as a component of polemics about the vices of bureaucracy. (Barnard, 1938; Blau and Scott, 1962; Brafman and Beckstrom, 2006; Brinkerhof, 1972; Burt, 1992, 1994; Carzo and Yanouzas, 1967; Cloi, Leiter and Dever, 2008; Ehlin, 1995; Jaques, 1976; Klein, 2010; Krackhardt and Hanson, 1993; Leibenstein, 1987; Nickerson and Zenger, 2004; Perrow, 1979; Peter and Hull, 1969; Rosengren, 1964; Simpson, 1969; Thayre, 1973). A variety of schemes have been advanced to blunt hierarchy's effects and cure its presumed dysfunctions (Klein, 2010; Lawler, 1988). Delayering reduces the number of levels in the hierarchy (Peters, 1987). Matrix organizations dilute it into dual structures.

Clans reduce its authoritarian and intrusive nature through the development of perhaps equally intrusive cultures (Ouchi, 1980; Ouchi and Jaeger, 1978). Autonomous work teams replace the hierarchy's lower terminus with "facilitators" (Katzenbach and Smith, 1993; Regans, 2003; Romme 1996). Decentralization, participative management, or empowerment, depending on which rubric is fashionable at the time, have sought to make it irrelevant. Worker councils and "double linking" seek to subject it to formal oversight by lower levels (Romme, 1996). Collectivist organizations (Brafman and Beckstrom, 2006; Rothschild-Witt, 1979) have sought to eliminate its decision making prerogatives altogether.

Despite much debate and considerable passion about the merits of and alternatives to hierarchy, relatively little comparable, systematic research into the actual workings of hierarchies has been undertaken (Probably the most notable and neglected work is that of Jaques (1976). Although no one would argue that managerial authority is irrelevant to the workings of organizations, it is equally unlikely that anyone believes that formal authority relations embodied in the chain of command are the only forces at work. It is not a recent observation that employees sometimes violate hierarchy by bypassing their immediate supervisor (Bernard, 1938). It is also axiomatic that informal arrangements frequently belie the orderly vision of a formal chain of command (Klein, 2010; Krackhardt and Hanson, 1993; Perrow, 1979). It is equally accepted that formal position in the hierarchy is not necessarily a good indicator of power in an organization (Crozier, 1964; Lawler, 1988). Nevertheless, systematic inquiry into the functioning of organizational hierarchies is curiously rare. Studies tend to be either large sample analyses of formal dimensions of organizations or case studies with rich detail but little comparative orientation. Without systematic research on hierarchies in action, there is little to guide descriptive or normative debate except general agreement that neither extreme is an accurate depiction of organizations.

This paper demonstrates a social network methodology for analyzing organizational hierarchies and ponders the theoretical significance of the results obtained. The data are 
part of a larger, but less detailed study of verbal networks across 65 organizations (Nelson, 2001; Nelson and Vasconcelos, 2007). Unlike the larger study, the four organizations in this paper were researched in considerable detail, including the history, culture, and composition of network groupings. This permitted the development of theoretical and empirical observations not possible in the larger study. The most notable finding of this research is that, in the four organizations studied, verbal networks of upper level employees were only tangentially related to the formal hierarchy, and the shape of the verbal networks themselves was more like an amoeba (a center periphery) than a pyramid (a hierarchy). Not only did network groupings contain mixtures of different hierarchical levels, the most central network groups included all hierarchical levels and sometimes even excluded the COO and other top managers.

An equally important finding is that the shape of verbal networks in all four organizations studied was the same, but that the composition of network groupings varied considerably from organization to organization and reflected the historical and cultural idiosyncrasies of the organization studied. The results also suggest that verbal network groupings better explained differences in perceptions of organizational culture than did hierarchical groupings, suggesting again the comparative marginality of formal hierarchy in the internal dynamics of the organizations studied. Finally, cultural differences were much greater between network groupings within the hospitals than between them.

\section{Blockmodel analysis of hierarchies}

Social network analysis attempts to draw a mathematical map of relations between actors and to identify patterns of interaction (Kilduff and Tsai, 2003; Nelson and Hsu, 2005; PerrySmith, 2006; Regans, 2003). This is particularly appropriate for the study of organizational hierarchies because the hierarchical chain of command is a recognizable pattern of relations between actors that can be expressed mathematically using a technique called blockmodelling (Burt, 1994; White, Borman and Breiger, 1976; Dorien, Batagelj and Ferligj, 2005). Paradoxically, network analysts to date have not studied formal hierarchical and mathematically derived permutations of relational data side by side despite the ease and intuitive appeal of doing so. Consider a matrix in which the $i, j$ cell reports the relation of $i$ to $j$ and the $j, i$ cell reports the relation of $\mathrm{j}$ to $\mathrm{i}$. Thus, if we ask $\mathrm{X}, \mathrm{Y}$, and $\mathrm{Z}$ if they like each other, and each person's response becomes one row vector of a matrix, we might get a result like this:

\section{$\mathrm{X} 011$}

Y 100

\section{$\mathrm{Z} 100$ (Note that the diagonal is empty)}

The above matrix indicates that $\mathrm{X}$ likes $\mathrm{Y}$ and $\mathrm{Z}$ and vice versa, but $\mathrm{Y}$ and $\mathrm{Z}$ do not like each other. Adapting this matrix to a hierarchy, we might ask $\mathrm{X}, \mathrm{Y}$ and $\mathrm{Z}$ who his/her boss is. A hierarchy would look like this: 
Expressed verbally-X has no boss, $\mathrm{X}$ is Y's boss, and $\mathrm{Y}$ is Z's boss.

Such a notational system permits us to study the operation of hierarchies more closely than traditional methods by asking members of the organization about different aspects of their relations with one another. In this study, I focus on frequent (defined as greater than 5 times per week) verbal contacts between employees. Of the many different kinds of contacts that can connect actors (dependency, information exchange, exchange of favors, liking etc.), frequent verbal contact is significant in organizations for a number of reasons. Most important are the psychological and social impact of frequent, face to face contact. Scholar's since Georg Simmell (1955), and especially George Homans (1950) have noted that relationships become stronger and share more affective content when they are frequent and carried out in real time. Mintzberg (1973) also noted that managers spend most of their time and accomplish most of their work in short verbal encounters. And Mark Granovetter, (1973) who framed the distinction between strong and weak network ties notes that frequency of contact is one of the most important dimensions of a network contact. Thus, a long line of scholars who study human contacts from a variety of perspectives point to frequent face to face contact as belonging to a fundamental and important kind of relationship which is different from a formally mandated organizational tie.

To collect network data, a list of all of the pertinent actors is prepared and each employee reports on his/her relations with everyone on the list. Responses are then set into an $\mathrm{NxN}$ matrix which provides a detailed map of the entire social network. Verbal ties that occur on average more than five times per week (once per business day) are coded as 1 , others, as 0 . Such matrices are usually too large for simple visual inspection, so they must be reduced to manageable proportions. In this study, data reduction is obtained through the generation of density tables. This is best demonstrated with a real example from the study. Below I reproduce the Hierarchical Permutation from Hospital C, found in table 4:

Table 1

Hierarchical permutation of verbal ties from Hospital C

\begin{tabular}{lllllll}
\multicolumn{3}{c}{ Raw Counts } & \multicolumn{3}{c}{ Densities } \\
Level & 1 & 2 & 3 & 1 & 2 & 3 \\
1 & 6 & 2 & 10 & .187 & .041 & .079 \\
2 & 4 & 0 & 3 & .083 & .000 & .018 \\
3 & 9 & 11 & 40 & .071 & .065 & .095 \\
$\mathrm{~N}=$ & 6 & 8 & 21 & & & \\
(Note: Level 1 includes COO and direct reports)
\end{tabular}


The entry for Cell 1,1 in the table of raw counts is 6, indicating that the 6 top level managers (including the COO) recognize 6 frequent contacts among themselves. The entry for Cell 1,2 of the table of raw counts is 2 , indicating that the 6 top level managers recognize 2 frequent contacts with the second level in the hierarchy. The entry for Cell 2,1 is 4, indicating that the 8 second level managers recognize 4 frequent contacts. In order to control for the number of actors in each hierarchical level, the number of realized contacts is divided by the number of possible contacts, yielding a "density" (Kilduff and Tsai, 2003). Between the 6 top and 8 second level managers there are 48 contacts possible $(6 \times 8)$. Dividing the number of realized contacts (2) by 48 yields the density of .041 , which is the entry for cell 1,2 of the density table. For diagonal cells, possible contacts are calculated by squaring the number of actors minus $\mathrm{N}$ to eliminate contacts with oneself. Thus the density for cell 1,1 is 6 divided by $6 \times 6-6$ or 32 , yielding a density of .187. Even casual study of this table yields some surprises. For instance, the third layer's verbal contact with the top layer is more intense than its contacts with its immediate supervisors in layer 2 . One notes also that the second and third layers recognize more contacts with their superiors than do their superiors (4 versus 2 for layer 2 and 11 versus 3 for layer three) but layer three and layer one are similar in their perceptions ( 9 and 10). It is also interesting that the first and third layers share frequent contacts among themselves while the second hierarchical level entertains no internal contacts.

\section{Another way to partition the verbal network}

Assuming (as we will demonstrate in the course of this paper) that partitioning our matrix by formal hierarchy does not yield the clearest possible representation of the overall network, it is desirable to consider also a mechanical clustering of the matrix based not on external criteria like hierarchy, but on the internal logic of the network itself. This makes for easier comparison of network groupings from one organization to another because it does not rely on formal organizational criteria which may vary from one institution to the next, but instead is derived from the data found in the matrix. A traditional principle for clustering matrices in network analysis is "structural equivalence" (Burt, 1992; Regans, 2003; Perry-Smith, 2006). Actors are structurally equivalent when their individual networks are identical. For instance actors $\mathrm{Y}$ and $\mathrm{Z}$ in my first example above are structurally equivalent because they like the same persons (Burt, 1992). Breiger Boorman and Arabie's (1975) Concor algorithm has been most commonly used to identify structurally equivalent network groupings and I use it here to analyze the overall network structure of the four hospitals studied. When Concor is used to partition the sociomatrix of Hospital C, we get a different, and perhaps clearer view of the social network of this hospital's salaried employees. (The number and selection of actors in each Concor group or "block" is determined by the algorithm and not by any formal organizational criterion.) Below I reproduce the Concor partition for Hospital C from table 4. 
Table 2

\section{Concor partition of verbal contacts from Hospital C}

\begin{tabular}{|c|c|c|c|c|c|c|c|c|c|}
\hline \multicolumn{10}{|c|}{ Concor Permutation } \\
\hline & \multicolumn{9}{|c|}{ Block Number } \\
\hline & 1 & 2 & 3 & 4 & & 1 & 2 & 3 & 4 \\
\hline 1 & 3 & 2 & 0 & 11 & & .002 & .021 & .000 & .092 \\
\hline 2 & 4 & 0 & 1 & 7 & & .042 & .000 & .025 & .087 \\
\hline 3 & 1 & 0 & 5 & 2 & & .017 & .000 & .250 & .040 \\
\hline 4 & 18 & 11 & 2 & 18 & & .150 & .130 & .040 & .200 \\
\hline & 12 & 8 & 5 & 10 & Block Size & & & & \\
\hline
\end{tabular}

Viewing this partition of the matrix, we see that group (also called a "block") Four contains many internal contacts (cell 4,4=18) in addition to extensive contacts with groups one and two. Block 3 has a high density of internal contacts for its size, and little contact with other groupings. Blocks one and two have few internal ties and few contacts with other blocks, with the exception of block four. Indeed, most of the matrix is empty except for ties within block four and between block four and other blocks. Viewed from this perspective, the social network of Hospital C managers resembles not a hierarchy, but a central clique tied to groupings with little internal contact, excepting group three, which forms a clique unto itself, isolated from all of the other blocks. This pattern is well known in sociology and anthropology as a center periphery (Dorien, Batagelj and Ferligj, 2005; Mardin, 1972; Rowlands and Kristiansen, 1987; Shils, 1975), but it has been generally ignored in organization studies - probably because of the predominance of hierarchical views of organizations. Almost as revealing as the overall pattern produced by the Concor algorithm is the composition of the four blocks, but a discussion of this feature of the data must await a more detailed description of the research setting and of the hospitals involved.

\section{Hospitals studied}

Five private general hospitals of similar size and case intensity were identified within a 50 mile radius. All were invited to participate in the study. Three ultimately contributed data. To add diversity to the study and gather additional data, I later included a community owned hospital of similar size from the same area when the opportunity arose. We gathered information about the history, strengths, weaknesses, and idiosyncrasies of the four hospitals through interviews with the COOs and selected employees of all of the hospitals studied as well as with outside academics and practitioners with a deep comparative knowledge of the regions' health care industry and of the histories and cultures of each hospital. We also studied data on 
the case intensity, financial performance, and technological sophistication of each institution. Verbal network data were collected by providing each salaried employee with a list of all other salaried employees and asking, among other things, for an estimate of the number of verbal contacts $\mathrm{s} /$ he had with each person on the list in an average week. Response rates varied from $55 \%$ for hospital D to over $90 \%$ for Hospital C.

While the hospitals studied were similar in size and technology, they varied considerably in management style and history. Hospital A was founded by independent physicians 65 years ago and experienced periods of oscillation between community and private ownership until it was purchased by a large corporation ten years before the study. The current administrator had a military background and made extensive use of bureaucratic controls. Hospital B, by contrast is only 9 years old and was planned and built by a large interstate corporation. Its current administrator has spent considerable energy and money in team building and worker empowerment. Perhaps expressive of its younger age and progressive management style, this hospital had one fewer hierarchical layers than the others - only three for all salaried employees versus four for the others (in all tables in this paper the COO is included with his direct reports).

Hospital $\mathrm{C}$ was founded 85 years ago by a charismatic doctor. Although it also was acquired by a major chain in the last decade, its history has been otherwise stable and it is still administered by the founder's son. This hospital retains a much more informal, family atmosphere than the other three. Hospital D is a community owned nonprofit that has been in operation for some 30 years. Local politics have intruded into its operations frequently, and a long tenured administrator was spectacularly dismissed by the board six years ago. His former assistant administrator now heads the hospital.

To summarize:

Hospital A: Has vacillated between community and private orientations over a long history. It is currently managed in a bureaucratic style by a retired military officer.

Hospital B: A young hospital that has invested heavily in team building and participative management.

Hospital C: An old hospital founded by a charismatic doctor now administered by his son. Has a long a stable history.

Hospital D: A community hospital with a long and turbulent history.

\section{Analysis of hierarchical partitions}

With this background, a narrative of results should be more meaningful and theoretically suggestive. When we view partitions of the four hospitals' verbal networks by hierarchy, we observe a pronounced absence of similarity from one organization to the next. (See table 4). Perhaps the most striking and easy to interpret hierarchical partition of the network data is found in Hospital B where there is a pronounced lack of differentiation between levels. (Recall that Hospital B has only three managerial layers and that I combine the COO and direct 
subordinates into one group.) There is ample contact between levels, but also substantial density within categories, with the possible exception of the second tier, which is perhaps slightly less cohesive internally than the top tier. Contrast this to the hierarchical permutation for Hospital A which contains a tightly knit top management team (cell 1.1's density is .833) and very little internal contact in the two lower levels (cell 2.2 and 3.3 densities are .137 and .000 respectively!) The third layer of the hierarchy has no frequent minimal internal contact and claims only 2 ties with the other layers. Hospital C has a similarly isolated layer with little internal contact and limited contact with the top, but in this case, it is layer two, not layer three. Interestingly, in Hospital C, layer three entertains fairly robust contact with layer one in a classic display of bypassing.

The asymmetries in the matrices are interesting also. The top management layer in Hospital A recognizes only four frequent contacts outside of its own level, and these - consistent with formal hierarchical principles - are all with the adjacent layer two. In contrast, layer two claims to have 13 frequent ties with level one and 11 with level two, far more than either level admits (4 for level one and 2 for level three). A similar disparity in perception occurs for layer three in Hospital $\mathrm{C}$ in relation to layer two but not for layer one. Layer three claims 11 frequent ties with layer two, against layer two's claim of 3 frequent ties. Lower status parties tend to overestimate contacts with higher status parties (Breiger, 1976; Nelson 1989) and parties alienated from another group tend to underestimate their frequency of ties to others, so these disparities may indicate conflict or inequality in parts of the hierarchies of Hospitals $\mathrm{A}$ and $\mathrm{C}$ respectively.

Hospital D looks somewhat like Hospital A, with a tightly knit top management team and an isolated and uncohesive third layer, but the ties between the second and first layer are somewhat weaker than in Hospital A, suggesting that top management in Hospital D is generally more isolated than in any of the other hospitals.

These results suggest rather strongly that despite similarities in size and technology of the hospitals, and despite the hierarchical nature of all three, the enactment of hierarchy — at least insofar as frequent verbal contacts enact the hierarchy - varies radically. In no case do the verbal contacts replicate the stair step chain of command portrayed by formal bureaucratic mandates.

\section{Structural equivalence (Concor) partitions}

If verbal networks of the formal hierarchy vary considerably from one hospital to the next, the structurally equivalent groupings generated by Concor are all rather similar. We encounter the paradox that the informal organizations of these hospitals are more similar than relations within and between the explicitly mandated hierarchical categories. All four hospitals' structurally equivalent groupings contain a dominant central group with high internal density and strong ties to at least one other block that has little internal cohesion. Compare blocks one and two for the Concor partition of Hospital A to blocks one and two of Hospital B, or to blocks four and one 
of Hospital C or groups three and two of Hospital D. The numbering of the blocks varies arbitrarily, but the pattern is the same - center periphery. There are additional blocks in all hospitals; Block three in Hospital A, Blocks one and two in Hospital C and block two in Hospital D are all isolates with little internal cohesion and few external contacts. And there are unconnected cliques in blocks three and four of Hospital B and block four of Hospital C. However, a strong central clique strongly connected to a periphery is evident in all four hospitals.

\section{Block composition}

Despite these structural similarities, there are fascinating differences in the composition of the blocks from hospital to hospital. The composition of blocks and their interrelations displayed both intriguing similarities and equally intriguing differences. In all four hospitals there was a block containing the administrator and or assistant administrator, the head of medical records, and/or the DRG coordinator and head of the business office. Such a grouping suggests a common functional logic bringing together the administrator with those who generate and evaluate information regarding the hospital's capacity utilization and financial standing. This "capacity utilization" block corresponds to block 1 hospitals A, and B, block 4 in C and block 1 in D (see table 4).

Another block found in all four hospitals contains diverse ancillaries and support services including heads of housekeeping, marketing or public relations, purchasing or supplies, physical therapy, radiology, surgical services and the like. These blocks share less in common across organizations and are more diverse internally than the blocks containing the administrator.

This "ancillary" block corresponds to block 2 in hospitals A, B, D, and to block 1 in hospital C. A final category of block contains a preponderance of nursing supervision or heads of units that are nursing intensive like obstetrics, intensive care or surgery. The nursing blocks correspond to block 3 in hospital A, 4 B, and 2 in C and 3 in D. Although the "capacity utilization block" typically contained more top level managers than other blocks, in no case did network groupings conform to the formal hierarchy; all blocks contained personnel from at least two and usually three layers.

Despite the fact that it was possible to identify commonalities in the functional composition of network groupings across the four hospitals, considerable individuality remained. Consider the "capacity utilization" block (block 1) of Hospital B. In addition to containing the administrator, DRG, business office, and medical records heads, this block contained the directors of materials, pharmacy, and food service. Thus, the central block at hospital B contained heads of the units that distribute things - food, medicine, bedclothes, bandages and the like - as opposed to services, throughout the hospital. No such distributors of things are found in the corresponding block of hospital D, and only pharmacy is found in the capacity utilization block of hospital A, and materials in hospital C.

Hospital $\mathrm{C}$ was most idiosyncratic of the four in the composition of its blocks. (It is

probably not coincidental that hospital $\mathrm{C}$ also had the longest independent existence and 
most stable history.) In hospitals $\mathrm{A}, \mathrm{B}$, and $\mathrm{D}$, most nursing jobs were confined to one or two blocks. Indeed, except for the director and assistant director of nursing at hospital $\mathrm{B}$, virtually all nursing positions at A, B, and D appeared in the second block of the initial 2 block Concor solution. In Hospital C, by contrast, no block has less than four positions with "nurse" in the job title.

In addition to its dispersion of nursing positions throughout the network, hospital C's blockings are generally more diverse and exhibit less functional logic. The "capacity utilization" block for instance contains the PBX supervisor, Head Nurses of Outpatient, Emergency Room, and Supervisor of Housekeeping, in addition to the expected DRG Coordinator, Director of Medical Records, and Assistant Administrator. The administrator per se is found in an isolate block with the manager of Food Services, Chief Occupational Therapy, and key personnel from the hospital's new Addictive Disease Unit. (My research assistants surmised that the Administrator liked to eat and drink a lot.) Block two, which contains the highest proportion of nursing personnel, nonetheless houses five non nursing personnel including the Risk Manager and Chief Lab Technician. (It is probably significant that Hospital C, with the most mixed composition in network groupings, had the most favorable assessment of its organizational culture of all of the hospitals. Unfortunately space does not permit presentation of these analyses here.)

The sole public hospital (D) is comparatively unremarkable in the composition of its blocks; it features clearly identifiable capacity utilization, ancillary, and nursing blocks like the others, with relatively few anomalies. Highly notable however, is the relationship between network structure and block composition. In hospitals A, B, and C, the capacity utilization block is the center, with the highest on-diagonal density and with strong reciprocal ties to the ancillary blocks. The "nursing" blocks are isolated, with few internal ties, except for block 4 of hospital B. In hospital D, however, the capacity utilization and ancillary blocks supply isolates and periphery respectively, and the center is provided by the nursing block.

Without further belaboring the description of network results, several interim conclusions seem appropriate: 1 . Structurally equivalent groupings shared more similarities across organizations than the pattern of strong ties obtained from partitions by formal hierarchy. 2 . Structurally Equivalent patterns deviated significantly from a classical hierarchical pattern in all cases. 3. Even in organizations of similar size and technology, the composition of center periphery groups is expressive of the historical and cultural idiosyncrasies of the organizations. 4. Although functional and hierarchical regularities are present in structurally equivalent groups, there is ample room for other influences on group composition. 5. It appears that it is possible for the logical central group of an organization to be displaced by a historically peripheral class - witness the dominance of the nursing blocks of hospital D versus the isolation of the capacity utilization block. To summarize:

Hospital A: Block composition is predictable and intuitive: clear Capacity Utilization, Ancillary and Nursing blocks are found. All nursing titles are confined to one block.

Hospital B: The central (capacity utilization) block has a "managers of things" component. Otherwise, block composition is much like others. 
Hospital C: Block composition is much less homogenous. Nursing is interspersed throughout blockings. The administrator is located in an isolate block.

Hospital D: Block composition is predictable and intuitive, but the structural relations are inverted; the Nursing block is central, Ancillaries peripheral, and Capacity Utilization is isolated.

\section{Hierarchy, verbal networks and perceptions of culture}

The portrait that is emerging thus far is one of organizations that are similar in form yet harbor significant differences as one digs deeper. The addition of cultural data deepens and enriches this emerging gestalt and suggests insights into the relation between structure and culture in organizations.

\section{Culture instrument}

This study used the C-VAT Aggregate Value Profile (AVP) to measure organizational culture (Nelson and Gopalan, 2003;) The AVP shares much in common with other quantitative approaches (See Alveson, 2002; Martin, 2002; and Rousseau, 1990 on the general merits and demerits of quantitative measures of culture.) The AVP does deviate in some regards however, because its development relied on the sociological and anthropological literature while most quantitative approaches to organizational culture are grounded in the social psychological literature. As a result, the AVP emphasizes more political and status themes than are found in the most of the work on organizational culture (Hawkins, 1984; Mardin, 1972; Rowlands, 1987). Manipulation, control, status, politics, hard work, and obedience are all themes found in the AVP that do not figure prominently in most measures of organizational culture. Some of the additional themes included efficiency, flexibility, harmony, speed, quality, loyalty, empathy, and planning.

The AVP contains 80 phrases divided into twenty sets of four. Subjects are asked to rank order phrases as descriptive of the real and desired culture of the organization (Perceptions of "real" as opposed to "ideal" values are the focus in this research because there was more variance in real culture than ideal values.). This procedure is reminiscent of Kilman's Culture Gap and Rokeach's personal value instruments except for their use of two phrases per set rather than four in the present instrument (Kilman and Saxon, 1983; Rokeach, 1973). Cluster analysis of the 80 phrases, generated 8 intuitive groupings which are named: Hurry, Good Work, Loyalty, Dominance, Politics, Status, Leadership, and Organization. Although I preferred cluster analysis for data reduction because it is more forgiving of nonmetric data and because of the large number of phrases (Nunnaly, 1978), factor analyses of subsets of these phrases generated very similar solutions. The cluster groupings provided the basis for scales, which were constructed by summing rankings from each cluster. 
Means, standard deviations, and intercorrelations for the 111 respondents from the four hospitals surveyed appear in Table 2. Interitem reliabilities on these scales were acceptable, especially considering that the mean intercorrelation of summed rankings cannot be positive (Kerlinger, 1986). Test retest reliabilities were computed on two administrations to $60 \mathrm{MBA}$ students taken one month apart. These also were acceptable (mean intercorrelation: .596).

\section{Culture results}

Table 6 reproduces the structural equivalence (i.e. Concor) density tables from Table 4 alongside the mean perceptions of culture for each block of each hospital. Useable culture instruments were obtained from $81,70,59$, and $40 \%$ of the population of interest for hospitals A and $\mathrm{B}, \mathrm{C}$, and $\mathrm{D}$ respectively. It should be kept in mind, therefore, that inferential statistics have less meaning for the first two hospitals, where only 19 and 30 percent of the population values are unknown. Statistical significance has somewhat greater importance for the last two (C and D) and of course for interorganizational comparisons. Variance accounted for is of greater conceptual interest in the analysis below.

The most obvious and theoretically important analyses are comparisons of partitions of the data set first by hospital, and then by hierarchy and network grouping within hospitals. Multiple discriminant analyses of both desired (ideal) and perceptions of real culture yielded no significant differences between hospitals and resulted in a maximum variance explained of only $27 \%$. Within all of the hospitals studied, on the other hand, differences between network groupings were greater than between organizations (variance accounted for ranged from 55\% for hospital C to $91 \%$ for hospital D) and three of four hospitals displayed significant differences in perception by network grouping while only one did for the hierarchical grouping. (Hospital C, the older hospital with the mixed network groupings showed no significant differences by network or hierarchical permutation.) Variance explained by structurally equivalent position was also greater than that explained by hierarchical position in all but Hospital A, where values were very close:

Table 3

Regressions of cultural perceptions on hierarchical and structurally equivalent partitions

\begin{tabular}{cccc} 
& \multicolumn{3}{c}{$\begin{array}{c}\text { Partition: } \\
\text { R Squared }\end{array}$} \\
Rospital & $\mathrm{N}$ & Hier. & Struared Eq. \\
A & 26 & $.62^{*}$ & $.57^{*}$ \\
B & 30 & .43 & $.73^{*}$ \\
C & 38 & .35 & .55 \\
D & 17 & .79 & $.91^{*}$
\end{tabular}

* Overall Equation Significant at .05 or less 
It would be difficult to overemphasize the conceptual importance of these results. Hospitals which are physically removed from each other, under different ownership, with different management and histories, vary less from each other culturally than do network groupings within hospitals. And network groupings are by and large much more influential in determining perceptions of culture than are one's position in the managerial hierarchy.

\section{Discussion}

Space will not permit presentation of further analyses, including comparison of real and ideal cultures, partitions of cultural data by hierarchy, and networks of weak ties. However, none of these analyses substantially alter the implications suggested by the data analyses presented above.

There seems to be little doubt that the most frequent contacts maintained in the four organizations studied followed patterns different from those predicted by principles of formal hierarchy. Hierarchical permutations of frequent verbal ties varied considerably from one hospital to the next and none closely matched a hierarchical pattern. At very least this suggests that the impacts of hierarchy on social processes can be quite different even among organizations of similar size in the same industry and geographic region. Thus critics and apologists alike may be unjustified in attempting broad generalizations about the dynamics of hierarchy until more is known about the differential impacts it can have. (See a similar argument about bureaucracy by Adler and Borgs, 1996).

While hierarchy did not constitute a uniform organizing principle in the hospitals studied, center periphery did. Very similar center periphery patterns surfaced in mechanical partitions of network data for all four hospitals, and network groupings shared important commonalities across organizations. Structurally equivalent groups in all organizations contained a common functional identity, but exhibited considerable individuality as described above. In one hospital (D), the central and peripheral block consisted primarily of personnel that composed isolate blocks in the other hospitals - essentially an inversion of roles. In another hospital (C) the administrator was found in an isolate block with minimal ties to other groups. There was also considerable variability in the degree to which nursing positions were confined to specific blocks and in the centrality enjoyed by blocks containing nurses.

The juxtaposition of network and cultural data validates the significance of centerperiphery in organizations and provides clues to its dynamics. It also, as DiMaggio (1992) and Martin, (2002) suggest, has implications for the study of organizational culture per se. There is a substantial association between center periphery structure and perceptions of organizational culture in all four hospitals studied, suggesting that the center periphery pattern is indeed socially meaningful. Moreover, the central blocks distinguish themselves in the degree to which they exhibit extreme high or low values, indicating that central groups set themselves apart from the rest of the organization in their perceptual vantage point. That center-periphery partitions of cultural data yield equal or greater associations than 
hierarchical permutations is perhaps the strongest indication of the importance of center periphery in the hospitals studied.

\section{Implications for the Study of organizational Cultures}

Much work on organizational culture has developed typologies supposed to describe cultures across broad varieties of organizations (Deal and Kennedy, 1982; Jones, 1989; Kakabadse and Kakabadse, 2002; Kets de Vries and Miller, 1989; Mitroff and Kilmann, 1975; Ouchi, 1981; Ouchi and Jaeger, 1978; Sethia and Von Glinow, 1985; Cooke and Rousseau, 1988). Somewhat more recently scholars have posited common cultural dynamics induced by characteristics of a firm's industry or economic sector (Abrahamson and Frombrun, 1994; Gordon, 1991; Porac, Thomas and Baden-Fuller, 1989; Sorenson, 2002).

As the study of culture in organizations has matured, however, the idiosyncrasies of individual cultures and the dissensual and subcultural aspects of organizations have also become more apparent (Martin, 2002; Robertson and Swan, 2004; Trice and Beyer, 1993) and the anthropological scholars that emphasize emic and "strain" perspectives (Geertz, 1973, for instance) have received more attention. However, because of their emphasis on diversity, the emic and subcultural approaches have not lent themselves to the formulation of general statements or broader theory building. Their contributions, by and large have been confined to "local theory" (Glaser and Strauss, 1967) building.

The findings yielded by the present research suggest ways that local and global approaches can be fruitfully combined. On the one hand there were no significant differences between perceptions of culture for the four hospitals studied, suggesting that despite considerable differences in institutional development, a common industry culture was present.

Against this common backdrop however, systematic, patterned variations appear - the perceived culture of one hospital's center was very much like the periphery of another, and the composition of one hospital's center was much like the periphery of the others. The extreme values in perceptions of culture for hospitals C and D were identical, and were perfectly inverted with the pattern of A's central group. Hospital B shared common network structure and similar block composition with A and C, but the subculture of its central group escaped the similarities and inversion found in the other three organizations.

These patterns are very much unlike the predictions of classic organizational theory from which much thought on organizational culture descends. Organization theory would generally predict that organizations of similar size and technology would contain similar dominant coalitions and patterns of interaction if not similar ideologies (see Hydebrand, 1973, for instance). What we see here, however, are similar ideological and relational templates applied in systematically disparate ways. The functional logic that would explain the central groups of hospitals A, B, and C, for instance, would have to be reversed to explain hospital D's center. In the same way, the values of central groups in $\mathrm{A}$ and $\mathrm{C}$, which are similar in functional composition, are polar opposites. While this pattern is foreign to most organization theory, 
it is very much like the inversions of common elements observed in center peripheries (Levi Strauss, 1963; Tcherkezoff, 1987).

Thus the organizations studied appear to respond to a common structural and cultural logic in different ways, probably as a function of idiosyncratic historical development and institutional context. Hospital C, with its charismatic origins and long and stable history (Wilkins and Ouchi, 1983) features somewhat attenuated oppositional dynamics and has network groupings that are functionally heterogeneous. With its short history and liberal management practices, Hospital B has developed a center with some unique technical elements and subcultures that escape the mold found in the other three. Probably in response to prolonged conflict, the functional grouping that corresponds to other hospitals' centers has become an isolate and the nursing block has taken over the central role of hospital D. Finally the military style leadership of Hospital A appears to have secured a homogenous and positive assessment of the culture from both central and peripheral groups, only to leave a small isolate group that is equally homogenous in its repudiation of central values.

The vision of culture that emerges when center periphery is the focus of attention is somewhere between the general theories borne of etic approaches and fine grained but idiosyncratic emic descriptions. The best metaphor I have found is Levi-Strauss' (1986) "bricoleur" - the French handyman-packrat who keeps a large collection of odds and ends on hand and intuitively knows how to assemble the varied elements of his inventory in creative ways that solve the diverse problems of the moment (Alveson, 2002; Baker and Nelson, 2005). The bricoleur neither designs from scratch as would an engineer, nor does he merely order replacement parts from a catalogue as would a mechanic. So it would appear with organizational cultures and networks. Neither do they perfectly replicate a standard repertoire nor do they emerge ex nihilo. Instead, they seem to select from the inventory of ideas, roles, and relations offered by the proximate environment some combination of elements that fit together. The resulting product may not always be aesthetic (it usually is) nor humane, but it is usually discernible and always interesting.

Table 4

\section{Hierarchical and Concor partitions of strong ties in four hospitals}

\begin{tabular}{ccccccc}
\multicolumn{7}{c}{ HOSPITAL A } \\
Level & 1 & 2 & 3 & 1 & 2 & 3 \\
1 & 5 & 4 & 0 & .833 & .095 & .000 \\
2 & 13 & 25 & 11 & .309 & .137 & .087 \\
3 & 0 & 2 & 0 & .000 & .016 & .000 \\
& $\mathrm{~N}$ & 14 & 9 & (Note: Level 1 includes COO and direct reports)
\end{tabular}




\begin{tabular}{|c|c|c|c|c|c|c|c|}
\hline \multicolumn{8}{|c|}{ Concor Permutation } \\
\hline & 1 & 2 & 3 & & & & \\
\hline 1 & 19 & 18 & 4 & & .211 & .180 & .067 \\
\hline 2 & 12 & 2 & 2 & & .120 & .022 & .033 \\
\hline 3 & 2 & 3 & 0 & & .033 & .050 & .000 \\
\hline & 10 & 10 & 6 & Block Size & & & \\
\hline
\end{tabular}

HOSPITAL B

Hierarchical Permutation

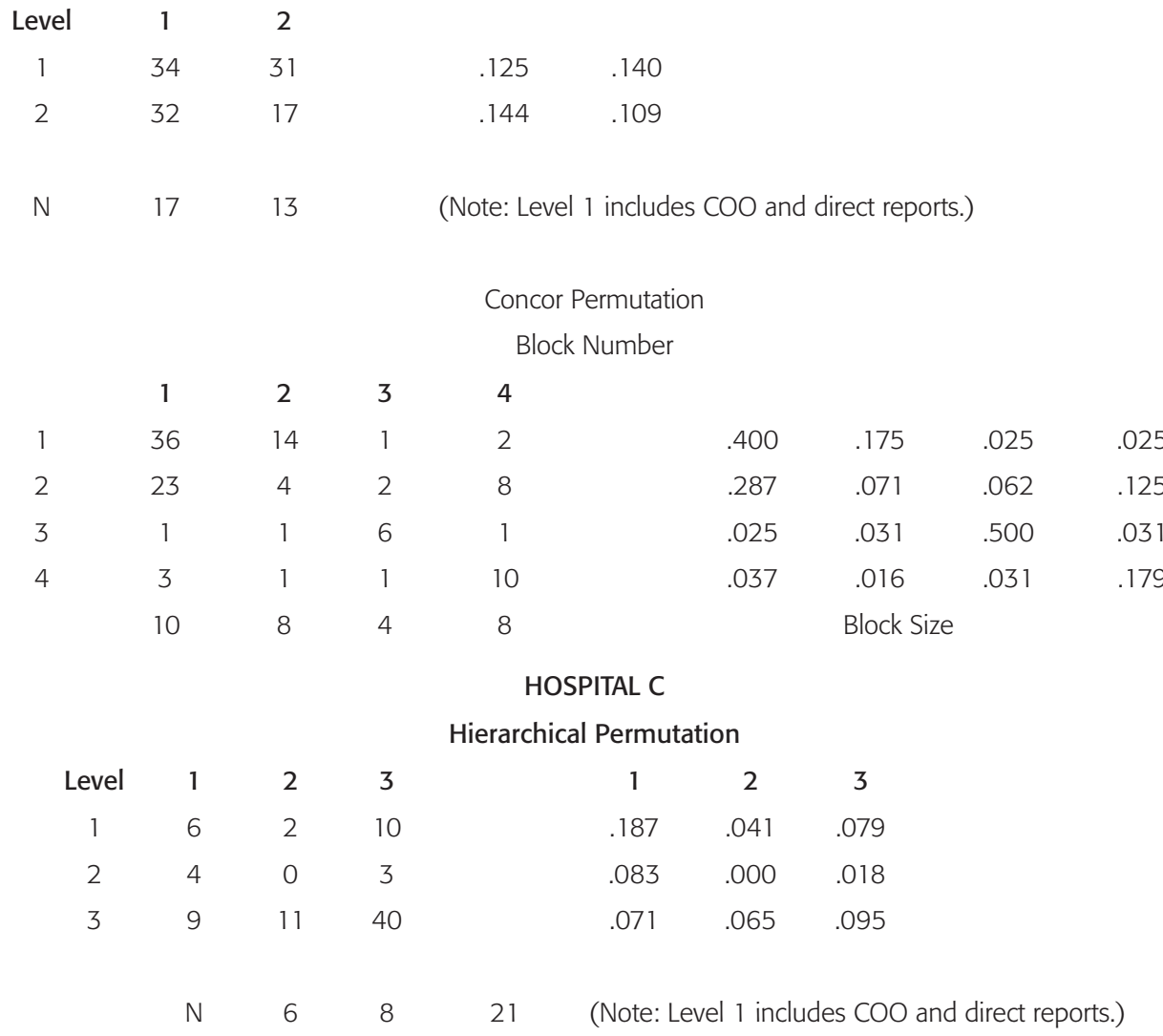

\section{Concor Permutation}

Block Number

$\begin{array}{llllcllll} & 1 & 2 & 3 & 4 & & & & \\ 1 & 3 & 2 & 0 & 11 & .002 & .021 & .000 & .092 \\ 2 & 4 & 0 & 1 & 7 & .042 & .000 & .025 & .087\end{array}$




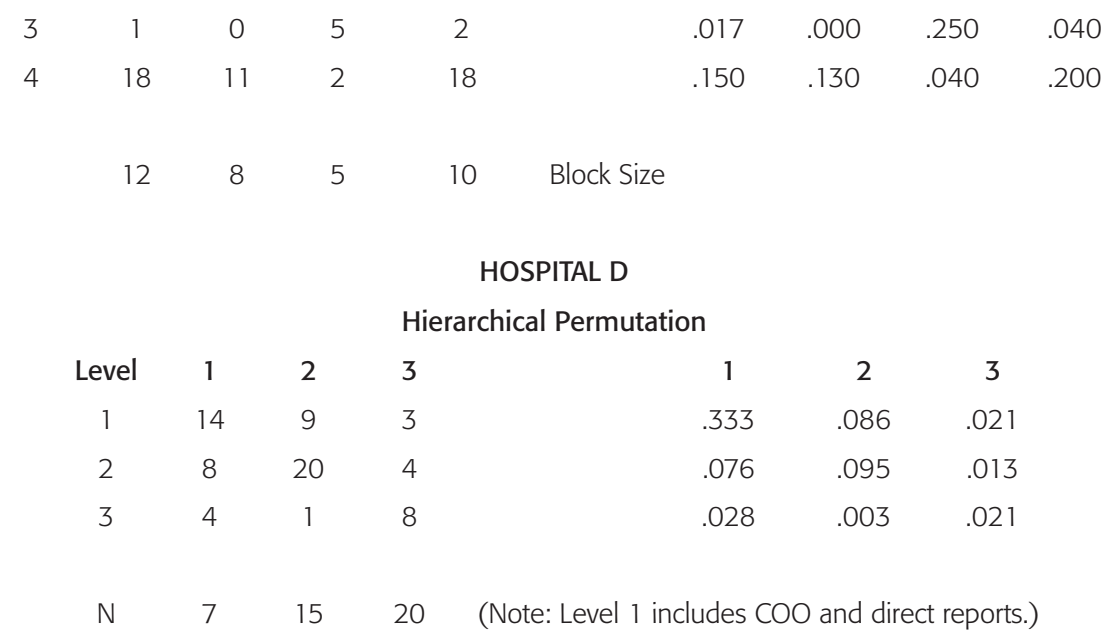

\begin{tabular}{ccccccc}
\multicolumn{7}{c}{ Concor Permutation } \\
Block Number \\
& 1 & 2 & 3 & 1 & 2 & 3 \\
1 & 18 & 0 & 4 & .047 & .000 & .017 \\
2 & 0 & 4 & 13 & .000 & .044 & .108 \\
3 & 4 & 11 & 17 & .017 & .092 & .129
\end{tabular}

Table 5

\section{Reliabilities of culture instrument}

$\begin{array}{lccc} & \text { Mean } & \text { S.D. } & \text { Alpha } \\ \text { Hurry } & 21.4 & 3.47 & .64 \\ \text { Good Work } & 37.3 & 6.46 & .77 \\ \text { Loyalty } & 37.7 & 7.38 & .71 \\ \text { Dominance } & 25.1 & 6.41 & .71 \\ \text { Politics } & 12.7 & 3.49 & .66 \\ \text { Status } & 18.5 & 3.63 & .71 \\ \text { Leadership } & 26.5 & 4.16 & .68 \\ \text { Organization } & 20.6 & 4.18 & .70\end{array}$

\begin{tabular}{|c|c|c|c|c|c|c|c|}
\hline \multirow[b]{2}{*}{ Hurry } & \multicolumn{7}{|c|}{ Intercorrelations } \\
\hline & -.24 & -.38 & .22 & .24 & .18 & -.34 & -14 \\
\hline Good work & & .19 & -.80 & -.67 & -.54 & .33 & .21 \\
\hline Loyalty & & & -.35 & -.27 & -.52 & -.18 & -.33 \\
\hline
\end{tabular}




\begin{tabular}{|c|c|c|c|c|}
\hline Dominance & .63 & .66 & -.52 & -.41 \\
\hline Politics & & .39 & -.46 & -.32 \\
\hline Status & & & -.29 & -.28 \\
\hline Leadership & & & & .52 \\
\hline Drganization & & & & \\
\hline
\end{tabular}

\section{Table 6 \\ Mean perceptions of culture for structurally equivalent (Concor) permutations of four hospitals}

HOSPITAL A

\begin{tabular}{llll}
\multicolumn{3}{l}{ Block Number } \\
1 & 1 & 2 & 3 \\
3 & 19 & 18 & 4 \\
12 & 2 & 2 \\
& 2 & 3 & 0 \\
10 & 10 & 6
\end{tabular}

Block Size

$\begin{array}{llll} & 1 & 2 & 3 \\ \text { Hurry } & 22.6 & 23.5 & 20.3 \\ \text { Good Work } & 37.4 & 37.3 & 31.0^{*} \\ \text { Loyalty } & 36.3 & 32.8 & 36.7^{*} \\ \text { Dominance } & 23.9 & 25.3 & 32.2^{*} \\ \text { Politics } & 13.0 & 13.1 & 15.0 \\ \text { Status } & 18.7 & 19.5 & 21.5 \\ \text { Leadership } & 25.9 & 27.6 & 24.2^{*} \\ \text { Organization } & 22.2 & 20.9 & 19.2\end{array}$

* One way Anova significant at .05

HOSPITAL B

Block Number

1

2

3

4

1

36

14

23

4

1

2

2

3

1

1

6

8

4

3

1

$1 \quad 10$

RAP - Rio de Janeiro 46(1):291-314, jan./fev. 2012 


\begin{tabular}{|c|c|c|c|c|c|}
\hline & 10 & 8 & 4 & 8 & Block Size \\
\hline & 1 & 2 & 3 & 4 & \\
\hline Hurry & 23.0 & 22.5 & 21.3 & 20.8 & \\
\hline Good Work & 36.8 & 38.1 & 38.5 & 39.1 & \\
\hline Loyalty & 36.5 & 34.5 & 42.5 & $37.4^{*}$ & \\
\hline Dominance & 23.9 & 26.8 & 24.8 & 25.9 & \\
\hline Politics & 13.8 & 12.8 & 11.5 & $10.8^{*}$ & \\
\hline Status & 16.7 & 19.1 & 17.0 & $19.3^{*}$ & \\
\hline Leadership & 26.4 & 26.6 & 25.0 & 27.9 & \\
\hline Organization & 22.9 & 19.9 & 19.5 & $19.0^{*}$ & \\
\hline \multicolumn{6}{|c|}{ HOSPITAL C } \\
\hline \multicolumn{6}{|c|}{ Block Number } \\
\hline & 1 & 2 & 3 & 4 & \\
\hline 1 & 3 & 2 & 0 & 11 & \\
\hline 2 & 4 & 0 & 1 & 7 & \\
\hline 3 & 1 & 0 & 5 & 2 & \\
\hline \multirow[t]{3}{*}{4} & 18 & 11 & 2 & 18 & \\
\hline & 12 & 8 & 5 & 10 & Block Size \\
\hline & 1 & 2 & 3 & 4 & \\
\hline Hurry & 20.7 & 22.4 & 17.8 & 19.6 & \\
\hline Good Work & 38.9 & 39.8 & 37.0 & $34.6^{*}$ & \\
\hline Loyalty & 38.9 & 40.2 & 43.8 & 40.5 & \\
\hline Dominance & 24.9 & 20.4 & 23.2 & $26.7^{*}$ & \\
\hline Politics & 12.0 & 11.5 & 12.8 & 13.0 & \\
\hline Status & 18.2 & 17.0 & 16.6 & 19.5 & \\
\hline Leadership & 26.9 & 26.0 & 27.2 & 26.8 & \\
\hline Organization & 19.6 & 22.6 & 21.6 & 19.3 & \\
\hline
\end{tabular}

HOSPITAL D

\section{Concor Permutation}

Block Number

$\begin{array}{ccccccc}1 & 2 & 3 & 1 & 2 & 3 \\ 1 & 18 & 0 & 4 & .047 & .000 & .017 \\ 2 & 0 & 4 & 13 & .000 & .044 & .108\end{array}$




$\begin{array}{lcccccc}3 & 4 & 11 & 17 & .017 & .092 & .129 \\ & 20 & 10 & 12 & \text { Block Size } & \\ & 1 & 2 & 3 & & \\ \text { Hurry } & 21.0 & 20.0 & 22.1 & & \\ \text { Good Work } & 41.5 & 39.0 & 30.7^{*} & & \\ \text { Loyalty } & 42.0 & 39.3 & 38.2^{*} & & \\ \text { Dominance } & 22.0 & 23.5 & 30.9^{*} & \\ \text { Politics } & 11.0 & 13.8 & 15.1^{*} & \\ \text { Status } & 18.8 & 14.8 & 19.2^{*} & \\ \text { Leadership } & 23.5 & 28.0 & 24.3^{*} & & \\ \text { Organiza- } & 17.8 & 21.8 & 18.3 & & \\ \text { tion } & & & & & \end{array}$

\section{References}

ABRAHAMSON, Eric; ROSENKOPF, L. Social network effects on the extent of innovation diffusion: a computer simulation. Organization Science, 8, p. 289-309, 1997.

ABRAHAMSON, Eric; FOMBRUN, Charles J. Macrocultures: determinants and consequences. Academy of Management Review, 19, p. 728-755, 1994.

ADLER, Paul S.; BORGS, Bryan. Two types of bureaucracy: enabling and coercive. Administrative Science quarterly, 41, p. 61-83, 1996.

ALVESON, Matts. Understanding organizational culture. Oxford: Unviersity Press, 2002.

BARNARD, Chester I. The functions of the executive. Cambridge, MA: Harvard University Press, 2002 [1938].

BAKER, Ted; NELSON, Reed E. Entrepreneurial bricolage: making something from nothing. Administrative Science Quarterly, 2005.

BENNIS, Warren G. Beyond bureaucracy: essays on the development and evolution of human organizations. New York: McGraw Hill, 1973.

BLAU, Peter M.; SCOTT, W. Richard. Formal organizations. San Francisco: Chandler, 1962.

BRAFMAN, Ori; BACKSTROM, Rod. A. The starfish and the spider: the unstoppable power of leaderless organizations. New York: Penguin, 2006.

BREIGER, Ronald L. Career attributes and network structure: a blockmodel study of a biomedical research specialty. American Sociological Review, 41, p. 117-135, 1976.

BRINKERHOF, Merlin B. Hierarchical status, contingencies, and the administrative staff conference. Administrative Science Quarterly, 17, p. 395-407, 1972. 
BURT, Ronald S. Contingent organization as a network theory: the culture performance contingency function. Acta Sociologica, 37, p. 345-360, 1994.

BURT, Ronald S.; CELOTO, Norm. The network structure of managerial roles in a large matrix firm. Evaluation and Program Planning, 15, p. 303-324, 1992.

CARZO, Rocco Jr.; YANOUZAS, John W. Formal organization: a systems approach. Homewood, Il: Richard D. Irwin, 1967.

CLOI, S.; LEITER, J.; TOMASKOVIC, Devon. 2008. Contingent autonomy: Technology, bureaucracy, relative power in the labor process. Work and Occupations, 36, p. 162-193, 2008.

COOKE, Robert A.; ROUSSEAU, Denise M. Behavioral norms and expectations: a quantitative approach to the assessment of organizational culture. Group and Organization Studies, 13, p. 245273, 1988.

CROZIER, Michael. The bureaucratic phenomenon. Chicago: University of Chicago Press, 1964.

DEAL, Terrence E.; KENNEDY, Allan A. Corporate cultures: the rites and rituals of corporate life. Reading, MA: Addison-Wesley, 1982.

DIMAGGIO, Paul. Nadel's paradox revisited: relational and cultural aspects of organizational structure. In: NOHRIA, Nitin; ECCLES, Robert G. (Ed.). Networks and organizations. Boston: Harvard Business School Press, 1992. p. 118-142.

DORIEN, Patrick; BATAGELJ, Vladimir; FERLIGJ, Anuska. General blockmodelling. Cambridge: Cambridge University Press, 2005.

EHLIN, Charles. The quest for empowering organizations: some lessons from our foraging past. Organization Science, 6, p. 666-671, 1995.

GEERTZ, Clifford. The interpretation of cultures. New York: Basic Books, 1973.

GLASER, Barney; STRAUSS, Anselm. The discovery of grounded theory. Chicago: Aldine, 1967.

GORDON, G. Industry determinants of organizational culture. Academy of Management Review, 16, p. 396-415, 1991.

GRANOVETTER, Mark S. The strength of weak ties. American Journal of Sociology, 78, 1360-1380, 1973.

HAWKINS, John. Inverse images: the meaning of culture, ethnicity and family in postcolonial Guatemala. Albuquerque, NM: University of New Mexico Press, 1984.

HOMANS, George. The human group. New York: Harcourt Brace, 1950.

HYDEBRAND, Wolf V. Comparative organizations: the results of empirical research. Englewood Cliffs, NJ: Prentice Hall, 1973.

JAQUES, Elliot. A general theory of bureaucracy. London: Heineman, 1976.

JONES, Michael O. In search of meaning: using qualitative methods in research and applications. In: JONES, Michael O.; MOORE, Michael D.; SNYDER, Richard C. (Ed.). Inside organizations: understanding the human dimension. Beverly Hills, CA: Sage, 1988. 
KAKABADSE, A.; KORAC-KAKABADSE, N. Essence of leadsership. London: International Thompson Business Press, 1999.

KATZENBACH, Jon R.; Douglas K. The wisdom of teams. Boston, MA: Harvard Business School Press, 1993.

KETS DE VRIES, Manfred; MILLER, Danny. The neurotic organization. San Francisco: Josey Bass, 1989.

KERLINGER, Fred. Foundations of behavioral research. New York: Holt Winston and Rheinhart, 1986.

KILDUFF, Martin; WENSIK, Tsai. Social network analysis. Thousand Oaks, Ca: Sage, 2003.

KILMAN, R.H.; SAXON, M.J. The Kilman-Saxon culture-gap survey. Pittsburgh, PA: Organizational Design Consultants, 1983.

KLEIN, Peter. The capitalist and the entrepreneur: essays on organizations and markets. Auburn: AL Ludwig von Misses Institute, 2010.

KRACKHARDT, D.; HANSON, J. Informal networks: The company behind the chart. Harvard Business Review, 71, 4, p. 104-111, 1993.

LAWLER, Edward W. Substitutes for hierarchy. Organizational Dynamics, 17, p. 4-15, Summer 1988.

LAWRENCE, Paul R.; LORSCH, Jay W. Organization and environment: managing differentiation and integration. Boston: Graduate School of Business Administration, Harvard University, 1967.

LÉVI-STRAUSS, Claude. Structural anthropology. New York: Basic Books, 1963.

LÉVI-STRAUSS, Claude. Anthropology and myth: lectures, 1951-1982. Oxford: Blackwell, 1986.

MARDIN, Serif. Center periphery: a key to Turkish politics? In: EISENSTADT, S.N. (Ed.). Post-traditional societies. New York: Norton: 1972. p. 169-190.

MARTIN, J. Organizational culture: mapping the terrain. Thousand oaks, CA: Sage, 2002.

MINTZBERG, Henry. The nature of managerial work. Harper Row, 1973.

MITROF, Ian; KILMAN, Ralph H. Stories managers tell: a new tool for organizational problem solving. Management Review, p. 18-28, July 1975.

NELSON, Reed E. The strength of strong ties: social networks and intergroups conflict in organizations. Academy of Management Journal, 32, p. 327-401, 1989.

NELSON, Reed E. On the shape of verbal networks in organizations. Organization Studies, 22, p. 797-824, 2001.

NELSON, Reed E.; VASCONCELOS, E. Industry Environment, Culture, and Verbal Networks in organizations. Management Research, v. 5, n. 3, p. 137-150, Fall 2007.

NELSON, Reed E.; GOPALAN, S. 2003. Do organizational cultures replicate national Cultures? Organization Studies, 24, p. 115-152, 2003. 
NELSON, Reed E.; HSU, Sonia. A network perspective on knowledge management. Encyclopedia of knowledge management. Hershey, PA: The Knowledge Group, 2005.

NICKERSON, Jack; ZENGER, Tood. A knowledge based theory of the firm: the problem solving perspective. Organization Science, 15, p. 617-632, 2004.

NUNNALY, Jun. C. Psychometric theory. 2nd ed. New York: McGraw Hill, 1978.

OUCHI, William G. Markets hierarchies and clans. Administrative Science Quarterly, 25, p. 129-140, 1980.

OUCHI, William. Theory Z: how American business can meet the Japanese challenge. Reading, MA: Addison Wesley, 1981.

OUCHI, William G.; JAEGER, Alfred M. Type z organization: stability in the midst of mobility. Academy of Management Review, 3, p. 305-313, 1978.

PERROW, Charles. Complex organizations: a critical essay. 2nd ed. Glenview, IL: Scot Foresman, 1979.

PERRY-SMITH, J.E. Social yet creative: the role of social relationships in facilitating Individual creativity. Academy of Management Journal, 49, 1, p. 85-101, Jan. 2006.

PETER, Laurence F.; HULL, Raymond. The Peter principle. New York: William Morrow, 1969.

PETERS, Tom. Thriving on chaos. New York: Harper and Row, 1987.

PORAC, Jeffery; THOMAS, H.; BADDEN-FULLER, C. Competitive groups as cognitive communities: the case of the Scottish knitwear manufacturers. Journal of Management Studies, 26, p. 397-415, 1989.

REGANS, R. 2003. Network structure and knowledge transfer: The effects of cohesion and Rangr. Administrative Science Quarterly, 48, p. 240-267, June 2003.

ROBERTSON, M.; SWAN, J. 2004. Control, what control? Culture and ambiguity within a knowledge intensive firm. Journal of Management Studies, 40, p. 831-858, 2004.

ROKEACH, Milton. The nature of human values. New York: Free Press, 1973.

ROMME, A.; GEORGES, L. A note on the hierarchy team debate. Strategic Management Journal, 17, p. 411-417, 1996.

ROTHSCHILD-WITT, Joyce. The collectivist organization: An alternative to rational bureaucratic models. American Sociological Review, 44, p. 509-527, 1979.

ROUSSEAU, Denise M. Assessing organizational culture: the case for multiple measures. In: SCHNEIDER, Benjamin (Ed.). Organizational climate and culture. San Fransisco: Josey-Bass: 1990. p. 153-192.

ROWLANDS, Michael; LARSEN, Mogens; KRISTIANSEN, Kristina. Center and periphery in the Ancient World. Cambridge: Cambridge University Press, 1987. 
SETHIA, Nirmal K.; VONGLINOW, Mary Ann. Arriving at four cultures by managing the reward system. In: KILMANN, Ralph H. et al. (Ed.). Gaining control of the corporate culture. San Fransisco: Jossey-Bass, 1985.

SHILS, Edward. Center periphery: essays in marcosociology. Chicago: University of Chicago Press, 1975.

SIMMEL, Georg. Conflict and the web of group affiliations. Glencone, IL: Free Press, 1955.

SIMPSON, Richard L. Vertical and horizontal communication in formal organizations. Administrative Science Quarterly, 14, p. 188-196, 1969.

SORENSON, O. The strength of corporate culture and the reliability of firm performance. Administrative Science Quarterly, 47, p. 70-91, 2002.

TCHERKEZOFF, Serge. Dual classification reconsidered: Nyamwez sacred kinship and other examples. Cambridge: Cambridge University Press, 1987.

THAYRE, Fredrick C. An end to hierarchy and competition: administration in the post affluent world. New York: New Viewpoints, 1973.

TRICE, Harry M.; BEYER, Janice M. The cultures of work organizations. Englewood Cliffs, NJ: Prentice Hall, 1993.

WEBER, Max. Economy and society. New York: Bedminster Press, 1968.

WHITE, Harrison C.; BOORMAN, Scott A.; BREIGER, Ronald L. Social structure from multiple networks: 1. Blockmodels of roles and positions. American Journal of Sociology, 81, p. 730-780, 1976.

WILKINS, Alan L.; OUCHI, William G. Efficient cultures: exploring the relationship between culture and organizational performance. Administrative Science Quarterly, 28, p. 468-481, 1983.

Reed Elliot Nelson is a professor at the Uninove Graduate School of Management and in the Department of Management, Southern Illinois University, EUA. E-mail: renelson@siu.edu. 